\section{Two views on UK research}

SIR - We were heartened to see your leading article "Dead-end for British research"' (Nature 26 July, p.261), highlighting the fact that imaginative research is being killed off in this country. We support your plea to the government to act quickly, but not the contention that it alone is the culprit. We were astonished that no mention was made of the fact that the people actually doing the research, respected senior and junior scientists throughout the country, saw the warning signs as long as ten years ago, which resulted in the formation of the Association of Researchers in Medicine and Science (ARMS) in 1978. The publicity in the scientific and lay press at the time of our lobby of Parliament in 1979, highlighted our concern in urging a major review of the whole research and development sector, and pointed out the irretrievable losses and delays to scientific and technological progress that would result if nothing was done (see Nature $\mathbf{2 8 2}$, $554 ; 1979$ ).

The basic problem lies not with the government but in the fixed attitudes in the research councils and universities as to how scientific research should be done. We believe that for research to prosper, at least some of it must become more professional, and not be exclusively the amateur parttime adjunct to teaching that it has historically been. This will necessitate establishment of research careers and recognition that the new graduate entering any research sphere needs training followed by probation. Recognized talent should then be rewarded with a career supervised by a body of professional researchers - as in any profession.

Despite our protests that today's young were more realistic and would turn away from research, to the detriment of research and the universities, nothing has been done. In fact, quite the reverse. The number of staff on short-term agerestricted grants has risen to 23 per cent of the university academic work-force, and the advice of the Advisory board for the Research Councils (ABRC) in July 1983 was to extend these contracts not curtail them. ABRC proposes to increase the number of short-term posts in units where a career structure actually exists in order, among other things, to "employ experts in some special or new technique to train existing staff"' (grants for not more than 3 years, and a maximum of 5 years). "Postdoctoral fellowships to attract scientists $(20-40)$ at the height of their scientific prowess to interact with existing staff" were also recommended (but to terminate in 3 years - positively without extension or renewal). All the above would be subject to the waiving of redundancy/unfair dismissal rights.
Are these attractive proposals? Why should the highly experienced, or the young, be used to "maintain the vigour and stimulus" of an outdated system, happy to discard them in 3 years or less? It shows no consideration for the people who will do the research, short or long-term, let alone for the quality of research such a sysem should produce. This smacks more of the treatment meted out by bullies to the nineteenth century chimney-sweep - not the advanced thinking vital for the sophisticated technology of the twentyfirst century one would expect from a board controlling the nation's research.

Small wonder that with the prospect that at thirty (now much older than their fellow graduates who opted for a job with some form of career advancement) they will be unemployable, the young are now scorning not only research but also science. Our prediction in 1979 that such continuing policies would confirm the United Kingdom's position as a third-rate economic and scientific power, with a complement of first-rate scientists and scientific opportunities going to waste, has really come to pass.

Our proposals would attract back the young graduate, but urgent action is also needed to prevent the irreparable loss of key senior personnel. Implementation of our proposals would involve a change in the dual support system. Since it has completely broken down as a result of government cuts, now is the time for action.

\section{Association of Researchers}

in Medicine and Science Limited, c/o Clinical Research Laboratories, Guy's Hospital,

London SE1 9RT, UK

SIR - Your leading article of 26 July is illjudged, ill-informed and opinionated. It is one thing to moan about the financial problems of British universities and research councils, but it is quite another to belittle the efforts and achievements of British scientists in teaching and research. That you can find nothing in recent British research to lift your spirit or stretch your imagination reflects, sadly, the state of your spirit and your lack of imagination (notwithstanding your doubtful clairvoyance in the matter of Nobel prizes) rather than any shortcomings on our part. You say that we should take steps to defend ourselves against mediocrity, but surely you must appreciate that almost all scientific research is "mediocre" insofar as it is unworthy of banner headings in Nature and unlikely to be rewarded with a Nobel prize.

A greater threat to British science than any supposed mediocrity within the research community is the onslaught of irrationality from without; for instance, you parody the British $\mathrm{PhD}$ system as "consisting of giving a young person a research problem and telling him [not her?] to come back when it is solved". If by this you mean that British research students are encourged to think for themselves then it is hardly, as you say, "amateurish"; or do all those foreign professionals whose work you so admire get someone else to do their thinking? Have you ever head of Brian Josephson, who did rather well as an "amateur" British research student by thinking for himself.

Perhaps you should try this thinking lark for yourself the next time you compose an editorial rather than just stringing together cliches. It takes some practice, but you might find it produces a more cogent argument, and one which focuses on the real problems affecting science.

NeIl Thomas

Department of Physics,

University of Birmingham,

PO Box 363,

Birmingham B15 2TT, UK

\section{Reform needed}

SIR - Somewhere in the back issues of Nature is the observation that, while in the nineteenth century the creative scientist could possibly expect starvation, in this century he is more likely to be buried in a mass of trivia. Unfortunately, public support for science also has more serious consequences, some of which are already evident. On the one hand, relatively large funding has attracted power-hungry people, (operators, grantsmen) into research, and on the other administration of these funds invokes the complementary bureaucratic ethos of playing it safe and other games of expediency and evasion. Consequently peer review, in principle the most cffective method of evaluation, is seriously distorted both by incompetence and by unidentified conflicts of interest, in particular undue influence of operator types. Decisions reached in this way are not subject to any form of appeal or accountability. Bureaucrats also seem remarkably insensitive to ethical issues, especially when they reveal embarrassingly poor judgement on their part.

A number of reforms are needed: (1) An effective appeals process; (2) accountability of review and award panels; (3) a precisely defined and strictly enforced code of ethics; (4) limitation of grant awards to those in which the grantee is performing directly on a day to day basis (that is, no absentee "principal investigators"').

It should be recognized that administration of science is a different undertaking from that of other public enterprises, since the primary unit is the individual investigator who should not be forced into the position of becoming an entrepreneur in order to survive. On the contrary it is the job of the administrator to protect him from political currents which have little to do with the practice of science.

University of Alabama,

M.C. GOODALl

Birmingham, Alabama 35486, USA 